\title{
THE INFLUENCE OF CAPITAL STRUCTURE, DIVIDEND PAY OUT ON FIRM VALUE AND FIRM PERFORMANCE : EVIDENCE FROM INDONESIA STOCK EXCHANGE
}

\author{
Indrayati* \\ *Lecturer in Accounting \\ Accounting Department \\ State Polytechnic of Malang, Indonesia \\ Soekarno-Hatta Road \\ No. 9 Malang East Java 65141 Indonesia. \\ Email: indrayati@polinema.ac.id \\ Indonesia
}

\section{ABSTRACT}

The purpose of this study is to test empirically the effect of leverage, investment stock, bond, and dividend policy on firm value and firm performance for agriculture, basic chemical industry, consumer goods, and finance on the Indonesian stock exchange. The population of this study is 632 companies listed on the Indonesian stock exchange, with a sample of 236 companies in 2018-2019, secondary data sources from ICDM, and audited financial reports by collecting documentation data and processing data with moderate multiple linear regression.

The findings of the research are that financial policy proxied by leverage, investment in stocks and bonds shows a significant positive effect on firm performance, and dividend policy also shows a significant positive effect on firm value. To increase the generalizability of research results, future studies will collect data with different populations or different countries. This study contributes to the performance and value of the company where the increase in leverage, investment, bonds, and dividends will increase the performance and value of the company. The implication of this research is to improve the performance and value of the company for the better. This research is limited to capital structure, dividend policy on firm value with firm performance as moderation. Further research can be developed with different samples and more for generalizations.

\section{Keywords: : capital structure, dividend payout, firm value, firm performance}

\section{Introduction}

To support the National development policy system, which focuses on the development of education, infrastructure, and poverty alleviation as well as equitable distribution of employment and income, to overcome the high level of intellectual unemployment, what an entrepreneur must do is invest. Technology for poverty alleviation by expanding access to information and markets with entrepreneurship, empowering open source technology to increase the nation's competitiveness. In 2017 there is a policy to inhibit investment for entrepreneurs carried out by the government, namely the approval of the Minister of Energy and Mineral Resources for changes in share ownership, transfer of interest, and management of companies, including changes in directors and/or commissioners (Minister Regulation ESDM No 42/2017).

Presidential Regulation dated January (1) (2018), will be a remedy for stagnation in investment. Hopefully, the business license can be completed in a matter of hours. With this step, world investment in Indonesia, which is currently low at $1.97 \%$ from an average of US \$ 1,417.58 billion per year, is expected to continue to increase. Investment realization will also continue to increase from an average of $27.5 \%$ for PMA and $31.8 \%$ for PMDN in 2010-2016 (Kontan Newspaper, Saturday, September 29, 2017). Economic policy package in the form of policies to accelerate investment licensing. Investment is the main driver of economic growth. 2019 economic growth of $5.01 \%$ direct investment contributed $33 \%$ of total national economic growth (Dutu, R, 2016; ElBannan, M, A, 2017, Gallup, 2014; Kusumajaya, 2011; Safrida, E, 2008; Varaiya, N, Kerin, RA, 1987).

Indonesia competes with neighboring countries aggressively for investment to grow the economy. Like Thailand, Vietnam, the Philippines, Myanmar made improvements to the investment climate to attract foreign investors to come. With the MEA, it is hoped that it will bring in foreign investment in the future. In this case, to support investment policy, it requires the availability of infrastructure, such as roads, ports, electricity, the availability of educated human resources from the education sector who need to be 
prepared to attract investment. By investing in the stock exchange, the application can be done online. Each year the stock exchange can conduct an IPO of 30 companies with an emission value of trillions (6T).

During one year the financial services authority managed funds of nearly 102 Trillion. For the coming years, the government is trying to increase the number of investors and investees. July 14, 2018, Indonesia officially purchased 88 trillion shares of PT Freeport with 51\% ownership, namely PT Inalum, as the leader of 3 state-owned mining companies. Inalum group provides funds of 21 trillion, while the rest is funded by debt of 33 trillion, for investment from 2018 to 2041, for 23 years, Indonesia can get a profit of 860 trillion. With companies incessant to conduct IPOs, there are opportunities for investors to invest in the stock market. If the stock price falls, investors can buy with the hope that in the future the stock price will rise, so that investors get a return on capital gain or an increase in stock prices. If the share price has gone up, investors can sell part of their share ownership to enjoy profits from the increase in share price (capital gain). Or it is owned until the end of the accounting period for dividend distribution or for life to control or control the firm if the performance of the firm is good. In the era of the AEC (Asian Economic Community), it will involve many aspects, including the free flow of goods, free flow of services, free flow of skilled labor, free flow of capital, and free flow of investment from Indonesia to Asian countries or from Asia to Indonesia. In the free flow of investment, investors will be free to invest either in Indonesia or in Asian countries.

In investing according to positive accounting theory and agency theory, it states that shareholders delegate responsibility to managers and employees to manage firm funds properly. To maximize firm value by managing or managing firm assets that can be obtained through debt, stock investment, and performing earnings management for the benefit of managers (agents), shareholders (principals), and other stakeholders such as creditors, investors, government, and other parties. involved with firm operations to find out where the firm's management performance, the increase in stock prices (capital gain) as well as firm value and the firm's market capitalization.

Astuti (2019) examines the effect of performance and capital structure on firm value in 13 automotive companies listed on the IDX in 2013-2017, the results show that performance and capital structure have a significant effect on firm value (Le, T.P.V, 2017; Martellini, Lmilhau, V, 2018; Apriyanti, C, 2015; Hoque, J. Hossain, A, 2014; Sucuahi, W, 2016).

The greater / higher the leverage, the greater the tendency for companies to choose accounting methods that increase profits. And companies with bonus programs tend to choose accounting methods that increase profits.
Husna (2018) examines the capital structure and firm performance on firm value in food and beverage companies with 70 observations, the results show that capital structure hurts firm value and firm performance has a positive effect on firm value. The relationship between stock investment and investment growth (IOS) creates wider economies of scale, product diversification, patents, trademarks, or brand loyalty (Chung and Charaenwong 1991). Cristie (1989) argues that investment in the investment opportunity set will be determined by the choice of business lines based on competitive advantage. Research by Smith and Watts (1992) states that investment growth will encourage earnings management so that it can increase compensation, with high investment growth tend to pay higher levels of compensation to top executives compared to the low investment opportunity set.

Managers as firm managers know more about the firm's internal information and the firm's prospects in the future compared to owners (shareholders). Therefore, as a manager, the manager is obliged to provide a signal about the condition or performance of the firm to the owner. The signal given can be known through the disclosure of accounting information such as financial reports. However, the information that the manager sends to the owner is sometimes received by the owner that does not match the actual conditions of the firm. This condition is known as information asymmetry. Information asymmetry occurs because managers are superior in controlling information compared to other parties (owners or shareholders). Information asymmetry will encourage the opportunist attitude of managers.

High dividends will affect the reaction of investors and firm value. The firm's performance can be reflected in high earnings per share, high dividends per share, high return on investment, high return on equity, and high return on assets. This can be influenced by the high level of debt and investment which is strengthened by the good management of firm agents and the high level of investment opportunities. This will also affect high investor reactions and high corporate value so that welfare for stakeholders can be achieved. Based on the description above, the effect of capital structure and dividend policy on firm value and firm performance is examined as a mediation on the Indonesian stock exchange.

\section{Literature Review}

\section{Positive Accounting Theory and Model Agency}

Theory (TAPAM)

Positive accounting theory states that shareholders delegate authority and responsibility to agents to manage firm funds properly (good corporate governance) and use accounting methods that maximize firm performance and value and increase stakeholder welfare. Agency theory states that the majority shareholder is the principal and as monitoring and 


\section{(C) Center for Promoting Education and Research (CPER) USA}

controlling agents as firm managers (Jensen \& Meckling, 1976).

\section{Investment Theory (Pecking Order Theory)}

This investment theory states that rational and riskaverse investors will consider the risk and return received in investing their funds. With good management of the funds obtained by the firm, it is hoped that it will be more prosperous and prosperous for shareholders.

\section{Leverage Theory (Bondholder Theory)}

Capital structure theory states that firm capital consists of internal and external capital, internal capital is the issuance of shares, and external capital is bank loans and bonds payable (Abor, J, 2005; Campbell, G, 2018; Devereux, M, P, Maffini, G, 2018; Kakilli Acaravci, S, 2015; Lachmann, L. M, 1978; Nimalathasan, 2010; Nurhikmah, D, 2013; Robichek, A \& Myers, C, 1966; Swanson, Z, Srinidhi, B.N, 2003; Welch, I, 2011).

\section{Residual Dividend}

This theory states that investors prefer to receive cash dividends and investors will get dividends after profits are used for additional investment (Ang, J, S, Fateni, A, 1997).

\section{Stakeholders Theory}

This theory states that the agent/manager of the firm will make every effort to operate the funds obtained by the firm from the principal either through debt, stock investment, bond sales, or SUN for the welfare of all parties involved in the firm (stakeholders) by using the funds obtained for reinvestment, innovation, product diversification to obtain optimal results/returns so that stakeholders will be more prosperous (McGuian, J, R, Moyer, R, C, 2011; Pandey, I, M, 2004; GitmanL. J, 2014). Company performance is the result of work or work performance achieved by the company during the company's operating period as measured by Tobins Q. Firm Value is jumlah ekuitas yang dimiliki oleh Perusahaan yang diukur dengan total Saham yang beredar dikalikan dengan Harga Saham Perusahaan (Vo, X.V \& Ellis, C, 2017). The conceptual framework and hypothesis of this study are:

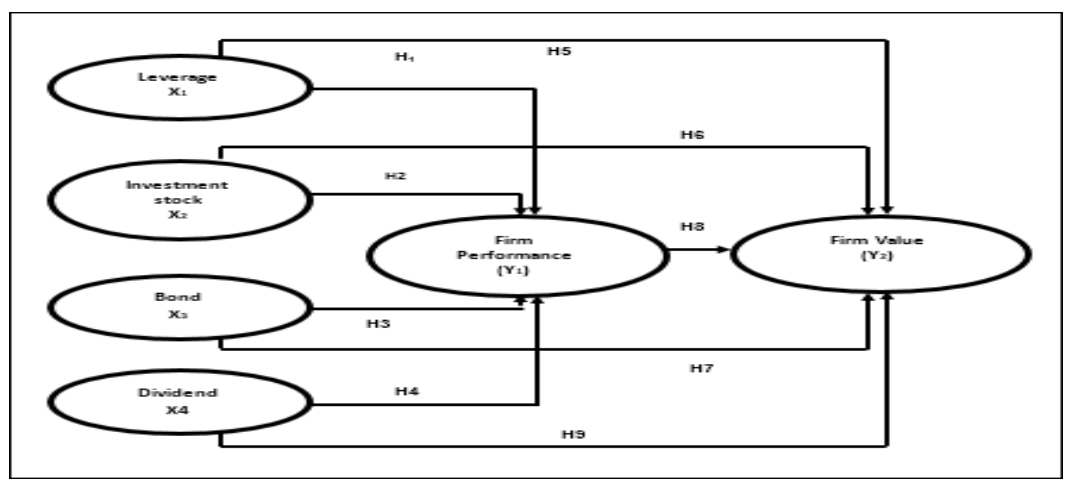

Figure 1: Conceptual Framework Model

\section{Research Hypothesis Development:}

H1: Leverage has a significant positive effect on firm performance

$\mathrm{H} 2$ : Investment has a significant positive effect on firm performance

H3: Bond has a significant positive effect on firm performance

H4: Dividend payout ratio has a significant positive effect on firm performance

H5: Firm performance has a significant effect on firm value

H6: Leverage has a significant positive effect on firm value

H7: Investment has a significant positive effect on firm value

H8: Bond has a significant positive effect on firm value

H9: Dividend payout ratio has a significant positive effect on firm value

\section{Research Methods}

\section{Research Design}

The design of this research is a quantitative research that applies and develops knowledge in the field of capital markets with the type of applied research which explains the influence and relationship of the independent variables of leverage, investment, dividend payout ratio to firm value with the following empirical research model:

Firm Performance $(\mathrm{Y} 1)=\mathrm{a}+\mathrm{b} 1$ Leverage $(\mathrm{X} 1)+\mathrm{b} 2$ Investment $(\mathrm{X} 2)+\mathrm{b} 3$ Bond $(\mathrm{X} 3)+\mathrm{b} 4$ Dividend $(\mathrm{X} 4)+\mathrm{e}$.

Firm value $(\mathrm{Y} 2)=\mathrm{a}+\mathrm{b} 1$ Leverage $(\mathrm{X} 1)+\mathrm{b} 2$ Investment $(\mathrm{X} 2)$ $+\mathrm{b} 3$ Bond $(\mathrm{X} 3)+\mathrm{b} 4$ Dividend $(\mathrm{X} 4)+\mathrm{b} 5$ Firm performance $(\mathrm{Y} 1)+\mathrm{e}$.

\section{Population and Sample}

The population in this study were 632 companies listed on the Indonesian stock exchange, with a research sample of 236 companies in 2018-2019 consisting of agricultural companies, basic chemical industries, consumer goods, and finance with the following details: 18 companies, 1 livestock, fishery 1 firm, Perhutani 1 firm, basic cement industry 6 companies, ceramic glass and glass 7 companies, metal and the like 15 companies, 13 chemical companies, 11 plastics, and packaging companies, 5 animal feed companies, wood and processing 2 companies, pulp and paper 9 companies, 2 companies, food and beverage companies 27 , cigarette 5 companies, 10 pharmaceutical companies, 6 


\section{(C) Center for Promoting Education and Research (CPER) USA}

cosmetics companies, 5 equipment, and other companies, 44 (Y1) both directly and through the firm performance variable banks, 16 financial institutions, 5 securities companies, (Y1) as an intermediary variable is as follows: insurance, and others 24 companies with a total 236 companies.

\section{Data Collection and Processing}

Secondary data sources were collected from ICDM and firm financial reports that were audited in 2018 and 2019 in the documentation then tabulated and processed using SPSS version 26.

\section{Research Results and Discussion}

\section{Hypothesis Testing}

In this study, the analysis used to test the proposed hypothesis is path analysis. Path analysis is used to determine the magnitude of the direct influence between exogenous variables on endogenous or indirect effects between exogenous variables on endogenous variables through intermediate variables.

The path model that will be sought to explain the functional relationship of the variable Leverage (X1), Stock Investment (X2), to Firm performance
- $\mathrm{Y}_{1}=\rho_{\mathrm{Y} 1 \mathrm{X} 1} \mathrm{X}_{1}+\rho_{\mathrm{Y} 1 \mathrm{X} 2} \mathrm{X}_{2}+\rho_{\mathrm{Y} 1 \mathrm{X} 3} \mathrm{X}_{3}+\rho_{\mathrm{Y} 1 \mathrm{X} 4} \mathrm{X}_{4}+\mathrm{e}$ .....................(1)

- $\mathrm{Y}_{2}=\rho_{\mathrm{Y} 2 \mathrm{X} 1} \mathrm{X}_{1}+\rho_{\mathrm{Y} 2 \mathrm{X} 2} \mathrm{X}_{2}+\rho_{\mathrm{Y} 2 \mathrm{X} 3} \mathrm{X}_{3}+\rho_{\mathrm{Y} 2 \mathrm{X} 4} \mathrm{X}_{4}+\rho_{\mathrm{Y} 2 \mathrm{Y} 1} \mathrm{Y}_{1}+$ e ..............(2)

Information:

$$
\begin{aligned}
& X 1=\text { Leverage } \\
& X 2=\text { Stock Investment } \\
& X 3=\text { Bonds } \\
& X 4=\text { Dividend } \\
& Y 1=\text { Firm performance } \\
& Y 2=\text { Firm Value } \\
& \quad e=\text { Contribution of other variables (error) } \\
& \rho_{x i y i}=\text { Path coefficient from exogenous to } \\
& \text { endogenous }
\end{aligned}
$$

\begin{tabular}{|c|c|c|c|c|c|c|c|}
\hline \multirow{2}{*}{$\begin{array}{c}\text { Sub- } \\
\text { Structural }\end{array}$} & \multicolumn{2}{|c|}{ Variable } & \multirow{2}{*}{$\mathbf{H}$} & \multirow{2}{*}{$\begin{array}{c}\text { Path } \\
\text { Coefficient }\end{array}$} & \multicolumn{2}{|c|}{ Partial Hypothesis } & \multirow{2}{*}{ Conclusion } \\
\hline & Exogenous & Endogenous & & & t-value & p-value & \\
\hline \multirow[t]{4}{*}{1} & Leverage (X1) & \multirow{4}{*}{$\begin{array}{l}\text { Firm } \\
\text { Performance } \\
\text { (Y1) }\end{array}$} & $\mathrm{H}_{1}$ & 0,244 & 2,742 & 0,007 & Significant Effect \\
\hline & $\begin{array}{c}\text { Investment Stock } \\
\text { (X2) }\end{array}$ & & $\mathrm{H}_{2}$ & 0,213 & 2,484 & 0,015 & Significant Effect \\
\hline & Bond (X3) & & $\mathrm{H}_{3}$ & $-0,236$ & $-2,940$ & 0,004 & Significant Effect \\
\hline & $\begin{array}{c}\text { The dividend } \\
\text { (X4) }\end{array}$ & & $\mathrm{H}_{4}$ & 0,230 & 2,680 & 0,009 & Significant Effect \\
\hline \multirow[t]{5}{*}{2} & Leverage (X1) & \multirow{5}{*}{ Firm Value (Y2) } & $\mathrm{H}_{5}$ & 0,143 & 2,718 & 0,008 & Significant Effect \\
\hline & $\begin{array}{c}\text { Investment Stock } \\
(\mathrm{X} 2)\end{array}$ & & $\mathrm{H}_{6}$ & 0,028 & 0,548 & 0,585 & Not Significant Effect \\
\hline & Bond(X3) & & $\mathrm{H}_{7}$ & 0,129 & 2,694 & 0,008 & Significant Effect \\
\hline & $\begin{array}{l}\text { The dividend } \\
\text { (X4) }\end{array}$ & & $\mathrm{H}_{8}$ & 0,005 & 0,105 & 0,917 & Not Significant Effect \\
\hline & $\begin{array}{l}\text { Firm } \\
\text { Performance (Y1) }\end{array}$ & & $\mathrm{H}_{9}$ & 0,824 & 14,904 & 0,000 & Significant Effect \\
\hline
\end{tabular}

The path model above shows that equation (1) explains the hypotheses $\mathrm{H} 1$ and $\mathrm{H} 2$, equation (2) explains the hypothesis H3. In detail, to find out how the results of the hypothesis test can be seen in detail as follows.

Table 1. Summary of Path Analysis Testing

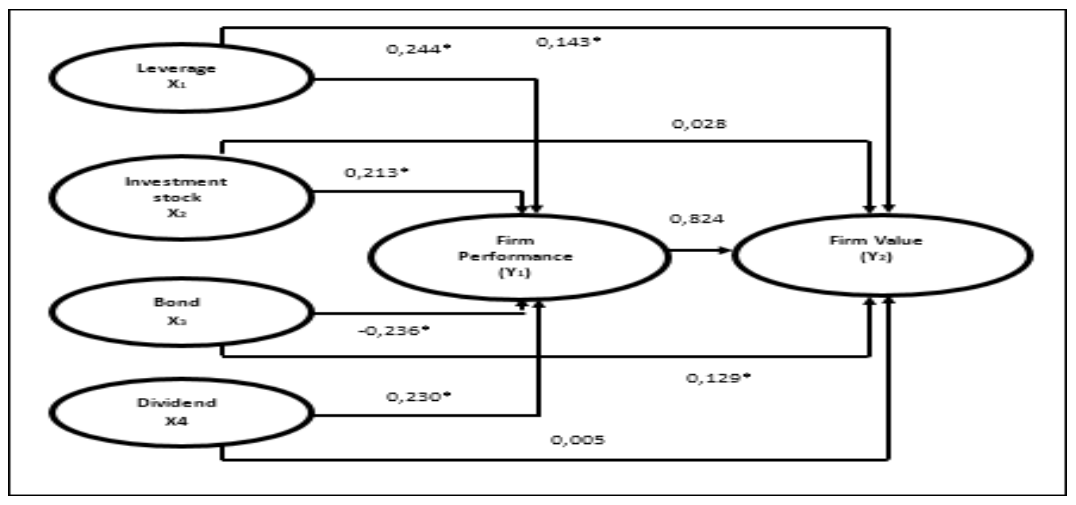




\section{CCenter for Promoting Education and Research (CPER) USA}

wWW.cpernet.org

Based on the table above, it can be seen that the results of estimation and hypothesis testing

1) on the variable leverage (X1) on firm performance (Y1) are known where the Path coefficient is 0.244 with a pvalue of 0.007 because the p-value is smaller than alpha (0.05), then the statistical hypothesis states Ho is rejected, meaning that leverage (X1) has a significant effect on firm performance (Y1).

2) In the stock investment variable (X2) on firm performance (Y1) where it is known that the Path coefficient is 0.213 with a $\mathrm{p}$-value of 0.015 . Because the $\mathrm{p}$-value is smaller than alpha (0.05), the statistical hypothesis states that Ho is rejected, meaning that stock investment (X2) has a significant effect on firm performance (Y1).

3) In the bond variable (X3) on firm performance (Y1) where it is known that the path coefficient is -0.236 with a pvalue of 0.004 , because the $p$-value is smaller than alpha (0.05), the statistical hypothesis states Ho is rejected, meaning that bond (X3) has a significant effect on firm performance (Y1).

4) In the dividend variable (X4) on firm performance (Y1) where it is known that the Path coefficient is 0.23 with a $\mathrm{p}$-value of 0.009. Because the p-value is smaller than alpha (0.05), the statistical hypothesis states that Ho is rejected, meaning that dividend (X4) has a significant effect on firm performance (Y1).

5) In the variable leverage (X1) on firm value (Y2) where it is known that the Path coefficient is 0.143 with a pvalue of 0.008 . Because the $\mathrm{p}$-value is smaller than alpha (0.05), the statistical hypothesis states Ho is rejected, meaning that leverage (X1) has a significant effect on firm value (Y2).
6) In the stock investment variable (X2) on firm value (Y2) where it is known that the path coefficient is 0.028 with a $\mathrm{p}$-value of 0.585 . Because the p-value is greater than alpha $(0.05)$, the statistical hypothesis states that $\mathrm{Ho}$ is rejected, meaning that stock investment (X2) affect, but not significant, to firm value (Y2).

7) In the bond variable (X3) to firm value (Y2), where the path coefficient is known to be 0.129 with a p-value of 0.008 . Because the p-value is smaller than alpha $(0.05)$, the statistical hypothesis states Ho is rejected, meaning that bond (X3) has a significant effect on firm value (Y2).

8) In the dividend variable (X4) on firm value (Y2) where it is known that the Path coefficient is 0.005 with a pvalue of 0.917 . Because the $\mathrm{p}$-value is greater than alpha (0.05), the statistical hypothesis states Ho is rejected, meaning that dividend (X4) affect, but not significant, to firm value (Y2).

9) In the variable firm performance (Y1) on firm value (Y2) where it is known that the path coefficient is 0.824 with a $\mathrm{p}$-value of 0 because the $\mathrm{p}$-value is smaller than alpha (0.05), the statistical hypothesis states that $\mathrm{Ho}$ is rejected, it means that firm performance (Y1) has a significant effect on firm value (Y2).

Furthermore, to find out how the indirect influence between leverage (X1) on firm performance (Y1) through firm value (Y2) and the indirect effect between stock investment (X2) on firm performance (Y1) through firm value (Y2), then the structure decomposition is carried out, namely multiplying the path coefficient of sub-structure 1 by sub-structure 2 .

Table 2. Indirect Effect between Variables

\begin{tabular}{|l|c|c|c|c|c|}
\hline \multicolumn{1}{|c|}{ Indirect Effect } & Count & Result & $\begin{array}{c}\text { t- } \\
\text { statistics }\end{array}$ & p-value & Information \\
\hline $\begin{array}{l}\text { Leverage (X1) on Firm } \\
\text { Value (Y2) through Firm } \\
\text { Performance (Y1) }\end{array}$ & $0,244 \times 0,824$ & 0,201 & 2,697 & 0,007 & Significant \\
\hline $\begin{array}{l}\text { Investment in Shares } \\
\text { (X2) to Firm Value (Y2) } \\
\text { through Firm } \\
\text { Performance (Y1) }\end{array}$ & $0,213 \times 0,824$ & 0,176 & 2,450 & 0,014 & Significant \\
\hline $\begin{array}{l}\text { Bonds (X3) to Firm } \\
\text { Value (Y2) through Firm } \\
\text { Performance (Y1) }\end{array}$ & $-0,236 \times 0,824$ & $-0,194$ & 2,884 & 0,004 & Significant \\
\hline $\begin{array}{l}\text { Dividend (X4) to Firm } \\
\text { Value (Y2) through Firm } \\
\text { Performance (Y1) }\end{array}$ & $0,23 \times 0,824$ & 0,190 & 2,638 & 0,008 & Significant \\
\hline
\end{tabular}


Based on the table above, it is known that the indirect effect between variables is as follows.

1) Indirect effect of leverage (X1) on firm value (Y2) through firm performance (Y1) is 0.201 with a p-value of 0.007 (Significant).

2) Indirect influence of stock investment (X2) on firm value (Y2) through firm performance (Y1) is 0.176 with a pvalue of 0.014 (Significant).

3) The indirect effect of bonds (X3) on firm value (Y2) through firm performance (Y1) is -0.194 with a p-value of 0.004 (Significant).

\section{References}

Abor, J. (2005). The effect of capital structure on profitability: an empirical analysis of listed firms in Ghana. The Journal of Risk Finance, 6(5), 438-445. https://doi.org/10.1108/15265940510633505

Ang, J. S., Fatemi, A., \& Tourani-Rad, A. (1997). Capital structure and dividend policies of Indonesian firms. Pacific-Basin Finance Journal, 5(1), 87-103. https://doi.org/10.1016/S0927-538X(96)00025-X

Apriyanti, C., \& Hamzah, M. Z. (2015). Pengaruh Kinerja Keuangan, Ukuran Perusahaan, Dan Struktur Aktiva Terhadap Struktur Modal perusahaan (Studi Kasus pada Perusahaan Manufaktur Sektor Industri Barang Konsumsi yang Terdaftar di BEI Tahun 2010-2015).

Astuti (2019), Pengaruh Struktur Modal dan Kinerja Terhadap Nilai Perusahaan.

Campbell, G., \& Rogers, M. (2018). Capital structure volatility in Europe. International Review of Financial Analysis, 55, 128139. https://doi.org/10.1016/j.irfa.2017.11.008

Christie, Andrew A. dan Jerold L. Zimmerman. (1994). Efficient and Opportunistic Choices of Accounting Procedures : Corporate Control Contests. The Accounting Review, Vol. 69, No. 4, October, 539 - 556.

Chung, Kee H dan Charlie Charoenwong, (1991).” Investment Option, Assets in Place and Risk of Stock”, Financial Management.

Devereux, M. P., Maffini, G., \& Xing, J. (2018). Corporate tax incentives and capital structure: New evidence from UK firmlevel tax returns. Journal of Banking and Finance, 88, 250-266. https://doi.org/10.1016/j.jbankfin.2017.12.004

Dutu, R. (2016). Why has economic growth slowed down in Indonesia? An investigation into the Indonesian business cycle using an estimated DSGE model. Journal of Asian Economics, 45, 46-55. https://doi.org/10.1016/j.asieco.2016.06.003

ElBannan, M. A. (2017). Stock market liquidity, family ownership, and capital structure choices in an emerging country. Emerging Markets Review, 33, 201-231. https://doi.org/10.1016/j.ememar.2017.11.001

Gallup. (2014). Country Data Set Details. Country Data Set Details Gallup World Wide Research Data Collected from 2005 2014. 1-127.

Gitman, L. J. and C. J. Z. (2014). Principles of Managerial Finance. 14th Edition. In Prentice Hall. https://doi.org/10.1016/0890-8389(89)90087-5

Hoque, J., Hossain, A., \& Hossain, K. (2014). Impact of Capital Structure Policy on Value of the Firm - a Study on Some Selected Corporate Manufacturing Firms Under Dhaka Stock Exchange. Ecoforum, 3(2), 77-84.

Jensen, M. C., \& Meckling, W. H. (1976). Theory of the firm: Managerial behavior, agency costs and ownership structure. Journal of Financial Economics, 3(4), 305-360. https://doi.org/10.1016/0304-405X(76)90026-X

Kakilli Acaravci, S. (2015). ***The Determinants of Capital Structure: Evidence from the Turkish Manufacturing Sector. International Journal of Economics and Financial. Issues, 5(1), 158-171. https://doi.org/10.1108/AJEMS-112012-0072

Kotler, P., Keller, K. L., Brady, M., Goodman, M., \& Hansen, T. (2016). Marketing Management. https://doi.org/10.1016/00246301(90)90145-T

Kusumajaya, . (2011). "Pengaruh Struktur Modal Dan Pertumbuhan perusahaan terhadap profitabilitas dan nilai perusahaan pada perusahaan manufatur di Bursa Efek Indonesia". Denpasar : Program Pasca Sarjana Universitas Udayana. 1-132.

Lachmann, L. M. (1978). Capital and its structure. In Hospital Topics. (Vol. 89). https://doi.org/10.2307/2551636 
Le, T. P. V., \& Phan, T. B. N. (2017). Capital structure and firm performance: Empirical evidence from a small transition country. Research in International Business and Finance, 42, 710-726. https://doi.org/10.1016/j.ribaf.2017.07.012

Martellini, L., Milhau, V., \& Tarelli, A. (2018). Capital structure decisions and the optimal design of corporate market debt prograams. Journal of Corporate Finance, 49, 141-167. https://doi.org/10.1016/j.jcorpfin.2017.11.011

McGuigan, J. R., Moyer, R. C., \& Harris, F. H. deb. (2011). Managerial Economics. In Cengage learning.

Nimalathasan, B., \& Ph.D, A. P. V. B. (2010). Capital Structure And Its Impact On Profitability: A Study Of Listed Manufacturing Companies In Sri Lanka. Revista Tinerilor Economisti (The Young Economists Journal), 1(15), 7-16. https://doi.org/10.4197/Eco.

Nurhikmah, D. (2013). Optimal Capital Structure Analysis a Study From Indonesia Telecommunication Companies Listed in Indonesia Stock Exchange Period 2009-2011. 2(1), 1-32.

Pandey, I, M. (2004). Financial Management.

Perusahaan, D. A. N. N. (2016). Pengaruh Struktur Modal Terhadap Produktivitas Aktiva, Kinerja Keuangan. (March).

Phusavat, K. (2013). Productivity Management in an Organization: Measurement and Analysis. In ToKnowPress. Retrieved from http://ideas.repec.org/b/tkp/tkpmon/978-961-6914-05-5.html

Robichek, a, \& Myers, C. (1966). Problems in the Theory of Optimal Capital Structure. The Journal of Financial and Quantitative Analysis, 1(2), 1-35. https://doi.org/10.2307/2329989

Safrida, E. (2008). Eli Safrida: Pengaruh Struktur Modal Dan Pertumbuhan Perusahaan Terhadap Nilai Perusahaan Pada Perusahaan Manufaktur Di Bursa Efek Jakarta, 2008. USU e-Repository () 2008. Skripsi.

Sucuahi, W., \& Cambarihan, J. M. (2016). Influence of Profitability to the Firm Value of Diversified Companies in the Philippines. Accounting and Finance Research, 5(2). https://doi.org/10.5430/afr.v5n2p149

Swanson, Z., Srinidhi, B. N., \& Seetharaman, A. (2003). The Capital Structure Paradigm: Evolution of Debt/equity Choices. Retrieved from http://books.google.com/books?id=U0ZWrqKLPG8C\&pgis=1

Syafruddin Ginting Sugihen: Pengaruh struktur modal terhadap produktivitas aktiva..., 2003 USU e-Repository (C) 2008. (2008). (2008). Syafruddin Ginting Sugihen: Pengaruh struktur modal terhadap produktivitas aktiva..., 2003 USU e-Repository (c) 2008.

Varaiya, N., Kerin, R. A., \& Weeks, D. (1987). The relationship between growth, profitability, and firm value. Strategic Management Journal, 8(5), 487-497. https://doi.org/10.1002/smj.4250080507

Vo, X. V., \& Ellis, C. (2017). An empirical investigation of capital structure and firm value in Vietnam. g/10.1016/j.frl.2016.10.014. Finance Research Letters, 22, 90-94. https://doi.or

Waters, D. (2011). Quantitative Methods for Business.

Welch, I. (2011). Two common problems in capital structure research: The financial-debt-to-asset ratio and issuing activity versus leverage changes. International Review of Finance, 11(1), 1-17. https://doi.org/10.1111/j.14682443.2010.01125.x

Yunina Yunina, Asmaul Husna, (2018). Pengaruh Struktur Modal dan Kinerja Keuangan Terhadap Nilai Perusahaan Pada Perusahaan Manufaktur Sub Sektor Makanan dan Minuman Yang Terdaftar Di Bursa Efek Indonesia (Periode 20122016). 